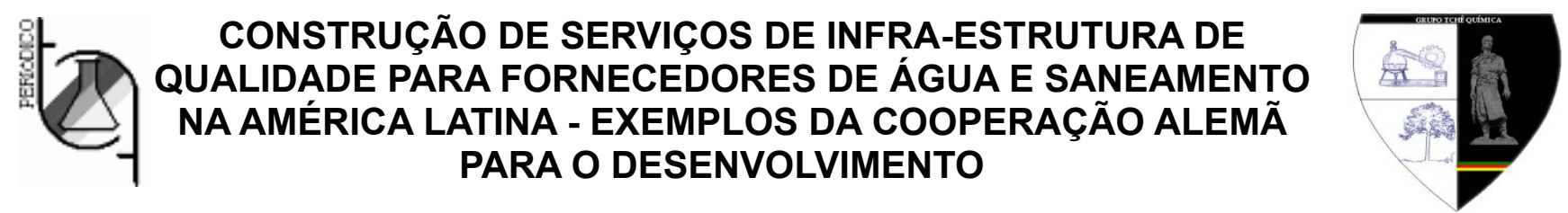

\title{
BUILDING QUALITY INFRASTRUCTURE SERVICES FOR WATER AND SANITATION PROVIDERS IN LATIN AMERICA - EXAMPLES FROM GERMAN DEVELOPMENT COOPERATION
}

\author{
RAMÍREZ, Ann-Katrin P. ${ }^{1}$; WOLFF, Carl F. ${ }^{2}$ \\ ${ }^{1}$ Consultant on behalf of the Physikalisch-Technische Bundesanstalt (PTB), Lima, Peru. \\ ${ }^{2}$ Physikalisch-Technische Bundesanstalt (PTB), Bundesallee 100, 38116 Braunschweig, Germany. \\ ${ }^{*}$ Autor correspondente \\ e-mail: carl.f.wolff@ptb.de
}

Received 15 November 2014; received in revised form 02 February 2017; accepted 05 May 2017

\section{RESUMO}

O Physikalisch-Technische Bundesanstalt (PTB) implementa projetos de cooperação para o desenvolvimento no domínio da infraestrutura de qualidade em nome do governo Alemão. Na América Latina, atualmente está cooperando com instituições em três países - Peru, Bolívia e Nicarágua - no campo da água e saneamento. Esses três países ainda enfrentam importantes desafios no fornecimento de água e saneamento em termos de cobertura de serviços, desenvolvimento institucional e fiscalização dos regulamentos setoriais. Além disso, a maioria dos prestadores de serviços não é capaz de garantir a exatidão das medições de quantidade ou a confiabilidade da análise da qualidade da água. A experiência do PTB provou que antes do projeto de intervenção água e saneamento geralmente não está no foco de órgãos da infraestrutura de qualidade. Mesmo que existam alguns serviços ou normas, eles geralmente não têm interação direta com o setor. No entanto, um exemplo do projeto de trabalho na Bolívia mostra que é possível aproximar os setores e a infraestrutura de qualidade através do desenvolvimento de serviços específicos. Prova de sucesso é a continuidade da participação dos provedores de água em testes de proficiência anual e também o número de laboratórios de análise de água que fazem parte de um programa de acreditação do setor. O exemplo do Peru, por outro lado, mostra como a introdução de um novo regulamento para o controle da qualidade das águas residuais industriais e comerciais lançadas no sistema de esgoto pode ser uma força motriz para trazer os órgãos da infraestrutura de qualidade e as instituições reguladoras para trabalharem juntos.

Palavras-chave: Água e saneamento; Qualidade, controle de qualidade analítico.

\section{ABSTRACT}

The Physikalisch-Technische Bundesanstalt (PTB) implements development cooperation projects in the area of quality infrastructure on behalf of the German government. In Latin America, it is currently cooperating with institutions in three countries - Peru, Bolivia and Nicaragua - in the field of water and sanitation. These three countries still face important challenges in water and sanitation provision in terms of service coverage, institutional development and enforcement of sector regulations. Furthermore, most service providers are not able to ensure the accuracy of quantity measurements or the reliability of water quality analysis. PTBs experience has proven that before project intervention water and sanitation is usually not in the focus of QI bodies. Even though some services or standards exist, they generally lack of direct interaction with the sector. Nonetheless, an example of project work in Bolivia shows that it is possible to bring the sector and QI bodies closer, through the development of specific services. Proof of success is the continuity of water utilities participating in annual proficiency tests and also the number of laboratories of water utilities being part of a sector accreditation program. The example from Peru, on the other hand, shows how the introduction of a new regulation for the control of the quality of industrial and commercial waste 
water released into the sewage system can be a driving force to bring QI bodies and the regulating institutions to work together.

Keywords: Water and sanitation; quality infrastructure, analytical quality control.

\section{INTRODUCTION}

The

Physikalisch-Technische

Bundesanstalt (PTB) is a technical authority of the German government under the auspices of the Federal Ministry for Economic Affairs and Energy being one of the oldest national metrology institutes of the world. It comprises more than 120 metrological laboratories for different measurement quantities, over 1800 employees and an annual budget of approximately 140 million EUR. PTB is one of the few metrological institutions in the world that implements technical cooperation projects with developing countries and emerging economies on behalf of the government. PTB's Technical Cooperation Department is currently implementing around 45 projects worldwide, with a yearly turnover of about 10 million EUR.

PTB's work is focused on the area of quality infrastructure (QI), which includes besides metrology - standardization, accreditation and conformity assessment. It pursues an integrated approach with the aim to build locally accessible, demand- oriented, technically competent and internationally recognized QI services that serve economic, social and environmental development. PTB understands $Q$ I to be a basis for fair trade conditions, regional integration and a crosscutting issue that has impact not only on industry and innovation, but also in areas such as public health, environmental protection, energy efficiency and renewable energies as well as good governance.

\section{DEVELOPMENT}

Since the year 2006 PTB has been implementing projects in support of the water and sanitation sector in Latin America, in particular in the field of drinking water. The first, still ongoing cooperation on this specific topic was with the Peruvian quality infrastructure bodies which are hosted by the INDECOPI (Instituto Nacional de Defensa de la Competencia y de la Protección de la Propiedad Intelectual). In 2010, a similar undertaking started with the Bolivian institute for metrology and accreditation IBMETRO (Instituto Boliviano de Metrología) and in 2013 a project with Nicaragua began, implemented jointly with the national metrology institute LANAMET (Laboratorio Nacional de Metrología) and the accreditation body ONA (Oficina Nacional de Acreditación).

The selection of these countries is not arbitrary but matches the priorities set by the respective governments in bilateral negotiations about technical cooperation. In Latin America, these are the only three countries where the water and sanitation sector has been defined as a focal area within German development cooperation. PTB, of course, is not the only implementing agency of the German government and its contribution is coordinated and implemented in a joint manner with the other executing arms such as $\mathrm{KfW}$ ( $\mathrm{KfW}$ Development Bank), GIZ (German International Cooperation) and BGR (Federal Institute for Geosciences and Natural Resources), supervised by a representative of the German Ministry for Economic Cooperation and Development in the German Embassies in these countries.

\section{EXISTING CHALLENGES FOR WATER AND SANITATION PROVISION IN LATIN AMERICA}

The three Latin American countries in which PTB is cooperating in the sector still face great challenges regarding basic water supply and sanitation services. The drinking water supply coverage, for example, ranges from more than $80 \%$ in Bolivia and Peru to only $64 \%$ in Nicaragua. Sanitation coverage lies still below these figures at around $73 \%$ in Peru, $52 \%$ in Nicaragua and $46 \%$ in Bolivia [1]. It is worth emphasizing that only a fraction of the waste water in the sewage system is appropriately treated.

Furthermore, the sector institutions and their governance are not yet fully developed. The existence of thousands of service providers 
in Bolivia poses a great challenge for the regulating and control authorities. Peru faces a similar situation, where more than a third of the population, living mainly in small towns and rural areas, is attended by service providers which are not adequately regulated or controlled [2]. The existence of a huge number of service providers outside the main urban areas makes it difficult to reach economies of scale that could enable the financial sustainability of these providers. The consulted studies [2] also call attention to the necessity of strengthening the governability of service providers, reducing political influence at municipal level and enabling the professionalization of the water industry. Additionally, as water pricing remains a very political issue in these countries, the actual tariffs tend to cover only the operational costs of the existing systems but are not designed to comprise maintenance or additional investments in the infrastructure.

The limitations described naturally impact on the quality of water supply services. Most service providers are not able to ensure the accuracy of quantity measurements (data on water balances and consumption) or the reliability of water quality analysis. With the exception of the water utility of La Paz, no other service provider in the three countries has its own accredited testing laboratory facilities. Even when accredited third party laboratories are available, the service providers are generally not required to make use of accredited testing services. In consequence, the regulator is unable to verify the accurateness of the reported results on water quality presented by the providers. Despite these serious limitations in the provision of safe drinking water, existing national standards and regulations for water quality are highly demanding, leaning on international standards. In accordance to the effective regulation, in Bolivia there are 59 parameters that should continually be controlled and reported to the regulator by service providers, while in Peru this can reach up to 120 , depending on the water quality at the source.

As is widely known, water quality has a direct impact on health, diarrheal disease being one of the leading causes of death in children under five years old as well as a cause of malnutrition. The under-five mortality rate in Bolivia is $61 / 1000$ live births, in Peru 25 and in Nicaragua $36[3]^{1}$. A significant proportion of

\footnotetext{
${ }^{1}$ As a comparison, the under-five mortality rate in Brazil is $20 / 1000$, Colombia $21 / 1000$ and Chile $9 / 1000$.
}

diarrheal disease can be prevented through safe drinking-water provision and adequate sanitation as well as basic hygiene. Additionally, there is a particular need for constant accurate water monitoring in rural areas where intensive agricultural or mining activities are undertaken, often contaminating the sources of drinking water.

In view of the escalation of water scarceness, especially for the Andean countries affected by climate change, service providers are forced to face new challenges regarding environmental concerns and waste water control. Currently Peru and Bolivia are increasingly addressing these matters, with new regulations coming into force. These requirements imply an increased control of waste water quality and environmental monitoring by the service providers.

\section{PTB'S COOPERATION APPROACH: ENHANCING QUALITY INFRASTRUCTURE SERVICES}

As explained before, the area of focus of PTB's technical cooperation work is quality infrastructure and therefore its natural implementing partners in the countries of cooperation are the national metrology institutes, national accreditation bodies and national standards bodies. The principal objective is to strengthen the QI institutions, their technical competence and their services for the relevant sector in a demand-oriented approach. Bearing this in mind, PTB's projects in the water sector are focusing on two major technical areas: 1) measuring water consumption = flow measurement and 2) measuring water quality of drinking or waste water.

PTB's experience from the past has shown that the water and sanitation sector is usually not in the focus of QI bodies. Some services or standards usually exist but generally a lack of direct interaction with this sector can be observed. In addition, the institutions of the water and sanitation sector have been found to have no or very little knowledge about the existence of a national $\mathrm{Ql}$ and the services it provides or potentially could provide. This important gap in communication and interaction needs to be addressed and is taken into 
account in project planning. The center of attention of PTB's projects lies in the increase of services provided by QI institutions fulfilling specific sector demands (supply-side approach). This is done through the training of technical personnel from the QI bodies, the acquisition of laboratory equipment, participation in interlaboratory comparisons, etc.

At the same time, efforts are being put into raising awareness and developing capacities of water and sanitation providers in order to enable them to make use of the services offered by QI (demand-side approach). Training courses are offered, for example, to technical personnel from laboratories for water quality as well as to technicians working in water meter testing. Furthermore, service providers are encouraged to participate in proficiency tests for water analysis and interlaboratory comparisons in flow measurement. Both intervention areas are complemented by support in the development and updating of relevant standards which is done by the stakeholders in technical committees organized by the national standards body.

\section{Safeguarding drinking water quality testing - an example from Bolivia}

From 2010 onwards, staff from 13 water suppliers in Bolivia have actively participated in several training courses offered by the partner institution IBMETRO and supported by the IBMETRO-PTB project. The laboratories of these water utilities have also taken part in the annual proficiency tests offered by IBMETRO with an average of 2.5 participations per utility. Although the providers had different success levels, the continuity of participation should be stressed here. During this period, PTB supported IBMETRO in the development of capabilities for the production of reference material for four of the five basic parameters from the national drinking water quality regulation [4]: $\mathrm{pH}$, conductivity, turbidity and free chlorine residual. As a consequence, in the proficiency test that is currently being offered (2014), only the microbiological reference material has to be acquired externally.

Aiming at promoting the enforcement of effective regulations, the Bolivian regulator Autoridad de Fiscalización y Control Social de Agua Potable y Saneamiento Básico (AAPS), together with the national accreditation body, is presently encouraging service providers to take part in a national program to promote the accreditation of their testing laboratories in two of the five basic parameters included in the Bolivian regulation on drinking water. IBMETRO and AAPS have identified around 16 water utilities with adequate infrastructure for testing these two parameters that are now requested to apply for participation. In a 14-month period the program involves a first assessment of the testing laboratory and provides several training courses, ending with an evaluation as part of the accreditation process. Costs are partially covered by the IBMETRO-PTB cooperation project but the water suppliers also cover essential parts of them, such as transport costs, the calibration of equipment, participation in proficiency tests and costs for obtaining and maintenance of the accreditation.

Even though this program is currently still at an early implementation stage, at present participants from 13 water suppliers have already registered. The results of this program will shed light on the feasibility of the intended regulation, forcing water utilities to regularly participate in proficiency testing schemes in the future.

\section{Securing waste water quality control - an example from Peru}

In Peru a new regulation has recently come into force which introduces controls for the quality of industrial and commercial waste water released into the sewage system $[5,6]$. Industrial and commercial users of municipal sewage systems are obliged to periodically report on their waste water quality in up 23 parameters, depending on the classification of their activity. For these reports the regulation only acknowledges the use of accredited testing laboratories. This new regulation aims at protecting the sewage systems as well as reducing the load of contaminants entering waste water treatment plants.

While there are a number of accredited testing laboratories covering all 23 parameters in the capital city of Lima, the situation is quite different outside Peru's capital, where these services are mainly not available. Industrial and commercial users of the municipal sewer system in the provinces are presently forced to take services from accredited laboratories in Lima, which cannot respond to this huge demand from the whole country.

With assistance from the INDECOPIPTB cooperation project a joint working group of INDECOPI and the Sanitation Head Office of 
the responsible housing ministry has been established and a program has been designed which will be executed with project funds during the period of about one year. The program will support capacity building in selected testing laboratories of the Peruvian provinces aiming at achieving a temporary authorization for testing by the sector authority and preparing them for the accreditation process. At present, 14 testing laboratories fulfilling the criteria for participation in the program have been identified. As soon as the legal situation regarding the temporary authorization is clarified, the program will start its work with a reduced group of these laboratories, carried out by technical experts recognized by the Peruvian accreditation body. The laboratories will have to bear part of the costs for the program.

\section{CONCLUSION}

PTB's technical cooperation work in the water and sanitation sector is following a stepby-step approach to improve the technical competence and availability of services provided by the national quality infrastructure while fostering at the same time the knowledge and competence of the sector stakeholders for the utilization of these services. The specific needs and priorities as well as local circumstances of the partner institutions are key for the success of the cooperation projects and guide the planning and implementation throughout the project cycle. Aspects of communication, the exchange of experiences and joint learning of the involved parties are of great importance in this endeavor, creating the basis for sustainable networks that last beyond the duration of projects and programs. These processes take time and cannot be successful in the short term. Meanwhile, the biggest challenge remains the limited financial endowment of the water and sanitation sector in most developing countries which makes it difficult to dedicate greater attention and the necessary resources to quality assurance and conformity assessment.

\section{REFERENCES}

1. WHO/UNICEF. Joint Monitoring Program for Water Supply and Sanitation, Report 2014 (data for 2012). Criteria for drinking water coverage: "piped onto premises". Criteria for sanitation coverage "improved facilities". 2014.

2. CEPAL. "Servicios de Agua Potable y Saneamiento en el Perú: Beneficios potenciales y determinantes del éxito", Santiago de Chile, 2010.

3. WHO. Global Health Observatory. Country Profile of Environmental Burden of Disease (2006 data), Geneva 2009.

4. Reglamento Nacional para el Control de la Calidad del Agua para Consumo Humano. Norma Boliviana 512, segunda revisión, diciembre 2010.

5. Decreto Supremo No. 021-2009VIVIENDA. Publicado en El Peruano, 20 de noviembre de 2009: 406305-406307.

6. Decreto Supremo No. 003-2011VIVIENDA. Publicado en El Peruano, 22 de mayo de 2011: 443045-443053. 